UDC 539.375

\title{
SEMI-ANALYTICAL METHOD OF FINISHED ELEMENTS IN ELASTIC AND ELASTIC-PLASTIC POSITION FOR CURVILINE PRISMATIC OBJECTS
}

\author{
V.A. Bazhenov, \\ Doctor of Technical Science \\ A.A Shkril', \\ Doctor of Technical Science \\ Yu.V Maksimyuk, \\ Doctor of Technical Science \\ I.Yu. Martyniuk, \\ Candidate of Technical Science \\ O.V. Maksimyuk \\ Kyiv National University of Construction and Architecture \\ Povitroflotsky Ave., 31, Kyiv, 03037
}

DOI: $10.32347 / 2410-2547.2020 .105 .24-32$

In $[4,5,6]$, the solving relations and the algorithm of the method of block iterations of solving linear and nonlinear equations by the semivanalytic finite element method for curvilinear inhomogeneous prismatic bodies are realized. This paper presents the results of the effectiveness of the semi-analytical finite element method for the consideration of curvilinear prismatic objects in elastic and elastic-plastic formulation in comparison with the classical finite element method.

Keywords: finite element method, semi-analytical finite element method, block iteration method, linear and nonlinear equations, elastic and elastic-plastic deformation, Michlin polynomials, curvilinear prismatic bodies.

Introduction. The choice of the optimal in terms of machine time and speed of convergence of the iterative process algorithm for solving systems of linear and nonlinear equations by semi-analytical finite element method $[1,2,3]$ is an important factor influencing the efficiency of the method as a whole. Numerous studies have shown that the use of the block iteration method to solve systems of equations of the semi-analytical finite element method for prismatic bodies with variable parameters has a number of important advantages over the solution of systems of the traditional version of the finite element method.

The organization of the computational process and its software implementation takes into account the basic requirements for software for calculating strength on modern software packages. The modular structure of the developed system of programs provides its non-closedness concerning new classes of tasks.

The purpose of this work is to show the effectiveness of the finite element method semianalitic consideration curvilinear prismatic objects in elastic and elastic-plastic formulation compared to the classical method of finite elements.

(C) Bazhenov V.A., Shkril’ A.A.,Maksimyuk Yu.V., Martyniuk I.Yu., Maksimyuk O.V. 


\section{Effectiveness of SAFEM application to the consideration of curvilinear prismatic objects in elastic and elastic-plastic formulation.}

A rational choice of the system of coordinate functions $\varphi^{l}$ significantly affects on the main criteria for the effectiveness of the semi-analytical method, such as the convergence of the iterative process of solving systems of equations and the accuracy of the solutions depending on the number of retained members of the schedule.

The easiest way to model various variants of fastenings is allowed by systems of basic functions that take zero values at the butt-end and are supplemented by Lagrange polynomials of zero and first order. It is proposed to use Michlin polynomials as such a system. There are other types of expansions that provide for the equation to zero displacements at the butt-end of the body, such as decomposition in a series along the sines.

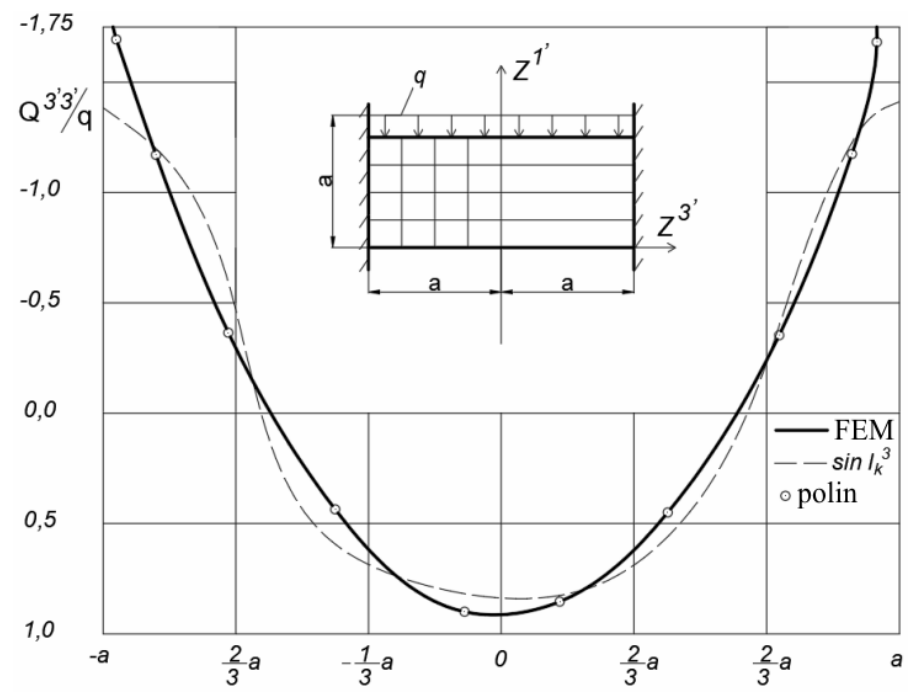

Fig. 1. Calculation of a prismatic beam considered in a flat statement

Let us compare these functions on the example of a prismatic beam rigidly fixed at the ends, which is considered in a flat formulation (Fig. 1), the reference solution of which is obtained by the finite element method. In solving of SAFEM task for both $\varphi^{l}$ the 5 members of the row were abstain. The calculations take the unit values of the modulus of elasticity of the material and the intensity of the uniformly distributed surface of the load body.

Analysis of stress distribution $\sigma^{33^{\prime}}$ along $Z^{3^{\prime}}$, obtained on the basis of both systems of coordinate functions showed, that Michlin polynomials provide a more accurate approximation of the parameters of the stress-strain state along the entire length of the body.

A comparison of the rate of convergence of the iterative process also shows, that using of Michlin polynomials is more acceptable than sinuses, as 
to obtain solutions with the same accuracy in the first case required 4 iterations, in the second - 5 .

Evaluation of the effectiveness of SAFEM when calculating objects with variables $Z^{3}$ physical and geometric parameters will be carried out by comparison with the traditional version of FEM.

The various modifications of the Gauss method are most widely used to solve systems of equations of the finite element method. At a constant width of the tape matrix of the system allowing the equations, the estimation of the volume of the required calculations can be conducted by comparing the required number of arithmetic operations to solve systems of linear equations of FEM and SAFEM.

The models with a regular structure of the grid area are considered. Assuming that in all coordinates the dimensions of the grid area are the same and equal to $n$, determine that the row width of FEM matrix tape is equal to $N_{p}^{\mathrm{FEM}}=\left(n^{2}+n+2\right) \cdot 3$ and SAFEM $-N_{p}^{\mathrm{SAFEM}}=(n+2) \cdot 3$, the total number of unknowns for both methods is equal to $n^{3}$.

For a system $\mathrm{M}$ of equations with a tape width of the matrix $\mathrm{N}$ performing a direct course of the Gauss method requires $M \cdot N \cdot(N-1)$ multiplication and $M \cdot N$ addition. When performing reverse required $\mathrm{M} \cdot \mathrm{N}$ multiplication and $M \cdot N$ subtraction. It is assumed that the operations of addition and subtraction take the same amount of time. Since the ratio of the width of the row of the matrix of FEM and SAFEM:

$$
\frac{N_{p}^{\mathrm{FEM}}}{N_{p}^{\mathrm{SAFEM}}} \approx n
$$

to perform the direct course of the Gauss method requires $n^{2}$ more multiplication and addition operations than for the SAFEM matrix, and to reverse $\mathrm{n}$ times more multiplications and additions. Using the method of block iterations the convergence of the solution of the systems of linear equations of SAFEM is achieved, on average, by $n$ iterations (at $\omega$ close to $\omega_{\text {op }}$ ). Considering, that the time of formation of the right part with equal parameters of the grid area the same for SAFEM and FEM, then numerical solution of the system of equations SAFEM using the algorithm investigated, requires 2 operations less than the solution of FEM equations by the Gauss method.

The efficiency of solving systems of equations by the method of block iterations is determined by several factors, such as convergence of the iterative process, determination of the optimal value of the relaxation parameter $\omega_{\text {op }}$ at the minimum computational costs and the effect of increasing the number of unknowns on the convergence rate.

A quantitative research is carried out on an example of elastic and elasticplastic deformation of an infinite strip with a rectangular cutout considered in the conditions of plane deformation (Fig. 2). At the butt-end of the boundary conditions are adopted, appropriate reliance on absolutely rigid in the crosssectional plane and the flexible diaphragm from it: 


$$
U^{1^{\prime}} / Z^{3^{\prime}= \pm 1}=\sigma^{3^{\prime} 3^{\prime}} / Z^{3^{\prime}= \pm 1}=0 .
$$

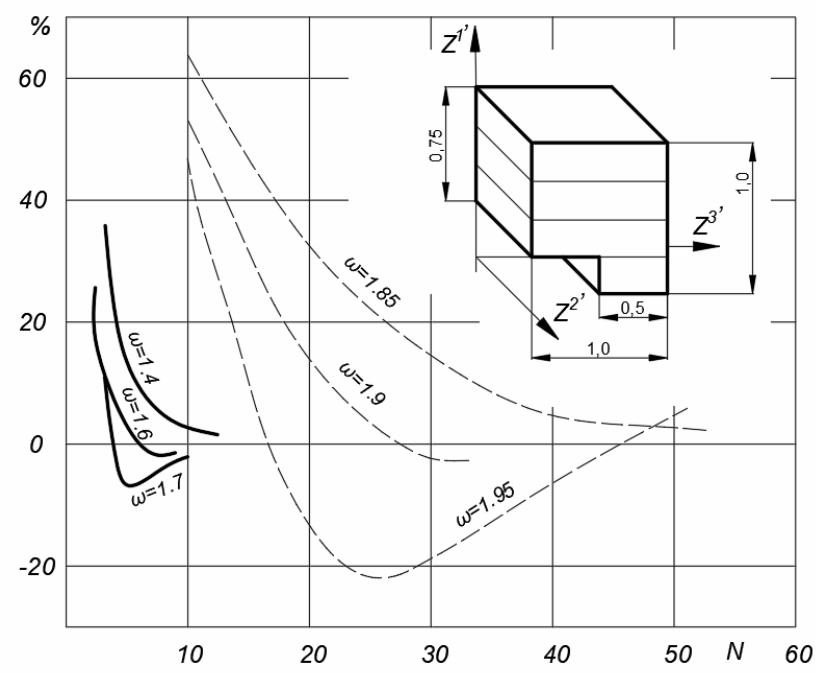

Fig. 2. Elastic and elastic-plastic deformation of an infinite strip with a rectangular cutout

On the upper surface of the body is applied uniformly distributed load intensity of which gradually increases from $0,3 \tau_{s}$ (elastic task) till $0,5 \tau_{s .}$ The modulus of elasticity of the material is taken equal to 1 , the Poisson's ratio 0,3 .

A necessary condition for the correctness of the results of SAFEM and FEM ratio is the same number of unknowns and the number of blocks in the matrices of systems of permitting equations. The calculations took the number of nodes of the grid region in the direction $Z^{3}$ at a finite element approximation equal to 9 , respectively, kept the first 9 members of the decomposition. Along $Z^{1}$ in both cases 13 nodes of the grid area were used.

The results of the study of the convergence rate of the block iterations method on the elastic deformation task at different values of the parameter $\omega$ for FEM and SAFEM are presented in Fig. 2. The allowable inaccuracy in calculating the maximum relative displacements was calculated as a percentage of the reference result obtained by the FEM using 289 grid nodes. The optimal values of the relaxation parameter were determined in accordance for FEM - $\omega_{\text {op }}=1,9$, for SAFEM - $\omega_{\text {op }}=1,6$.

Analysis of the curves shows that the rate of convergence of the iterative process in solving systems of linear equations of SAFEM s 5 times higher than for FEM.

Determine $\omega_{\text {op }}$ is a time-consuming process and to carry it out rationally on the basis of a more liquid finite element grid, so as not to repeatedly solve the problem with a large number of finite elements. In this regard, studies of the change in the rate of convergence of the iterative process with increasing 
number of blocks in the matrix at a fixed value of $\omega$ on the example of elastic deformation of the strip with a cutout.

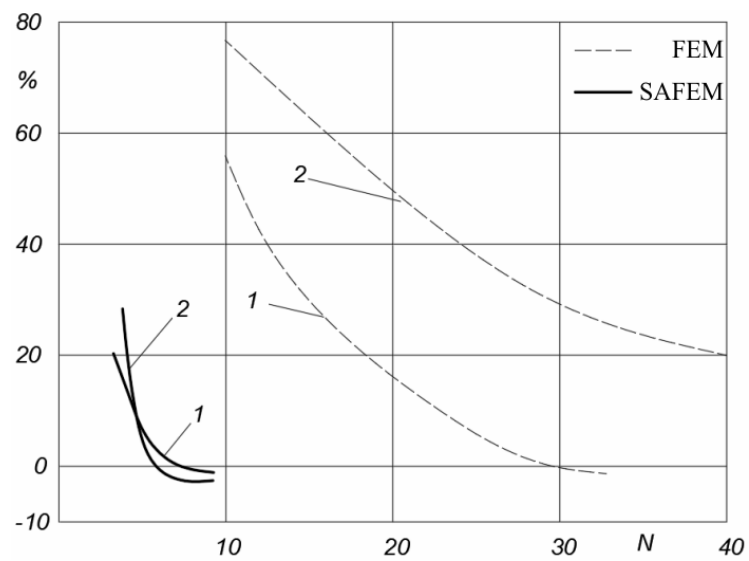

Fig 3. Permissible inaccuracy in determining the maximum displacements from the number of iterations

At optimal values of $\omega$, the convergence of the block iteration method was studied for the given grid area with an increase of 1,5 times respectively the number of finite elements along $Z^{3}$ or retained basis functions. The results are shown in Fig. 3 in the form of graphs that show the permissible inaccuracy in determining the maximum displacements from the number of iterations. The number 1 indicates the graphs obtained for the reference grid area, 2 - for the specified. The figure shows that the increase in the number of blocks in a matrix SAFEM does not affect the rate of convergence of the iterative process. The figure shows that the increase in the number of blocks in a matrix SAFEM does not affect the rate of convergence of the iterative process, while for FEM matrix it leads to a significant (2,2 times) increase in the number of iterations.

The curves characterizing the dependence of the number of iterations on the value of the relaxation parameter for the elastic-plastic calculation are shown in Fig. 4. Analysis of the data indicates a significant advantage of SAFEM for a class of the tasks considered. Thus, at the maximum level of development of plastic deformations, the iterative process for SAFEM converges 5 times faster than for FEM. However, the actual reduction in the amount of calculations is much greater due to a significant reduction in additional research to determine the optimal value of the relaxation parameter $\omega_{\text {op }}$.

Analysis of the nature of the graphs for the finite element method shows that the relaxation parameter should be chosen from the narrow neighborhood $\omega_{\text {op }}$, because failure the condition $\omega=\omega_{\text {op }}$ leads to a significant deterioration in the convergence of the computational process. With increasing level of plastic deformation there is a shift of the optimal value of $\omega$ in the direction of increase, but the convergence of the iterative process in solving the problem of 
plasticity by semi-analytical method at $\omega_{\mathrm{op}}=1,70$ - determined at the last step load is only $5 \%$ better than at $\omega_{\mathrm{op}}=1,6$, found in the first step of the load, while for FEM the use of the value of $\omega_{\mathrm{op}}=1,9$, the optimal at $\varepsilon_{p}^{\max }=0 \%$ gives an increase in the number of iterations by $40 \%$ compared to $\omega_{\mathrm{op}}=1,95$, determined in the last step of the load.

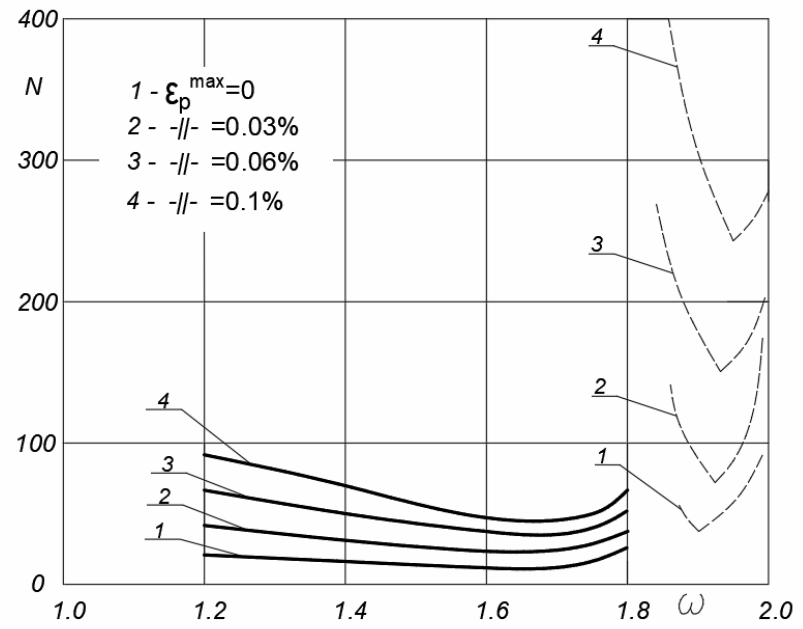

Fig. 4. The dependence of the number of iterations on the value of the relaxation parameter for the elastic-plastic calculation

Consequently, solving the FEM problem requires more time-consuming preliminary studies at maximum levels of plastic deformation to determine the optimal value of the relaxation parameter which is not required when using the semi-analytical variant, because $\omega_{\text {op }}$, which was found in the first load step, provides good convergence and next steps.

Conclusion. On this basis, it is advisable to determine the optimal value of the relaxation parameter for the semi-analytical method on a liquid grid and in the elastic stress region, because the same value is optimal on dense grids, and the shift in plasticity problems does not lead to a significant reduction in computational volume with the required costs at the relaxation parameter optimal for the elastic problem. Using the finite element method to search for $\omega_{\text {op }}$, it is necessary to repeatedly solve a physically nonlinear problem without reducing the size of the grid area, which requires significant quantitative research.

Using block of iterations to solving systems of nonlinear equations SAFEM about an order of magnitude performance dominates the traditional finite element method. 


\section{REFERENCES}

1. Bazhenov V.A. Neliniine deformuvannia ta stiikist pruzhnykh obolonok neodnoridnoi struktury (Nonlinear deformation and stability of elastic shells of inhomogeneous structure) / V.A. Bazhenov, O.P. Kryvenko, M.O. Solovei - K. : ZAT «Vipol», 2010. - 315 p.

1. Bazhenov V.A. Chyselne modeliuvannia protsesiv neliniinoho deformuvannia til $\mathrm{z}$ urakhuvanniam velykykh plastychnykh deformatsii (Numerical modeling of nonlinear deformation processes of bodies taking into account large plastic deformations) / V.A. Bazhenov, Yu.V. Maksymiuk, I.I. Solodei, R.L. Stryhun - Kyiv: "Karavela”, 2019. - 223 p.

2. Bazhenov $V$. A. Napivanalitychnyi metod skinchennykh elementiv $\mathrm{v}$ zadachakh ruinuvannia prostorovykh til : Monohrafiia (Semi-analytical method of finite elements in problems of destruction of spatial bodies: Monograph) / V. A. Bazhenov, O. I. Huliar, S. O. Pyskunov, O. S. Sakharov - K. : KNUBA, 2005. -298 p.

3. Huliar O.I. Universalnyi pryzmatychnyi skinchenyi element zahalnoho typu dlia fizychno i heometrychno neliniinykh zadach deformuvannia pryzmatychnykh til (Universal prismatic finite element of general type for physically and geometrically nonlinear problems of deformation of prismatic bodies) / O.I. Huliar, Yu.V. Maksymiuk, A.A. Kozak, O.V. Maksymiuk // Budivelni konstruktsii teoriia i praktyka - 2020. - Issue 6. - P. 72-84.

4. Maksymiuk Yu.V. Alhorytm rozviazannia systemy liniinykh ta neliniinykh rivnian napivanalitychnym metodom skinchenykh elementiv dlia kryvoliniinykh neodnoridnykh pryzmatychnykh til (Algorithm for solving a system of linear and nonlinear equations by the semivanalytic finite element method for curvilinear inhomogeneous prismatic bodies) / Yu.V. Maksymiuk, M.V. Honcharenko, I.Iu. Martyniuk, O.V. Maksymiuk // Budivelni konstruktsii teoriia i praktyka - 2020. - Issue 7. - P. 101-108.

5. Maksimyuk Yu.V. Basic relations for physically and geometrically nonlinear problems of deformation of prismatic bodies (Основні співвідношення для фізично і геометрично нелінійних задач деформування призматичних тіл) / Yu.V. Maksimyuk, S.O. Pyskunov, A.A. Shkril, O.V. Maksimyuk // Opir materialiv i teoriia sporud. - 2020. - Issue 104. P. 255-264.

Стаття надійшла до редакиії 03.09.2020

Баженов В.А., Шкриль А.А., Максимюк Ю.В., Мартинюк І.Ю., Максимюк О.В.

\section{НАПІВАНАЛІТИЧНОГО МЕТОД СКІНЧЕННИХ ЕЛЕМЕНТІВ У ПРУЖНІЙ І ПРУЖНОПЛАСТИЧНЫЙ ПОСТАНОВЦІ ДЛЯ КРИВОЛІНІЙНИХ ПРИЗМАТИЧНИХ ОБ'ЄКТІВ}

В статті наведені результати ефективності застосування напіваналітичного методу скінчених елементів до розгляду криволінійних призматичних об'єктів у пружній та пружно-пластичній постановці в порівнянні з класичним методом скінчених елементів.

Ключові слова: метод скінченних елементів (МСЕ), напіваналітичного метод кінцевих елементів (ПМКЕУ), метод блокових ітерацій (МБІ), лінійні і нелінійні рівняння, пружне і пружно-пластичне деформування, поліноми Михлина, криволінійні призматичні тіла.

\section{Bazhenov V.A., Shkril' A.A.,Maksimyuk Yu.V., Martyniuk I.Yu., Maksimyuk O.V. \\ SEMI-ANALYTICAL METHOD OF FINISHED ELEMENTS IN ELASTIC AND ELASTIC-PLASTIC POSITION FOR CURVILINE PRISMATIC OBJECTS}

In $[4,5,6]$ the algorithm of the method of block iterations of solving linear and nonlinear equations by the semivanalytic finite element method for curvilinear inhomogeneous prismatic bodies is realized. This paper presents the results of the effectiveness of the semi-analytical finite element method for the consideration of curvilinear prismatic objects in elastic and elastic-plastic formulation.

The choice of the optimal in terms of machine time and speed of convergence of the iterative process algorithm for solving systems of linear and nonlinear equations by the semivanalytic finite element method $[1,2,3]$ is an important factor influencing the efficiency of the method as a whole. Numerous studies have shown that using the block iteration method to solve systems of 
equations of the semivanalytic finite element method for prismatic bodies with variable parameters has a number of important advantages over solving systems of the traditional variant of the finite element method.

The organization of the computational process and its software implementation takes into account the basic requirements for software for calculating strength on modern software packages. The modular structure of the developed system of programs provides its non-closedness concerning new classes of tasks.

The use of the block iteration method to solve systems of nonlinear equations of SAFEM is approximately an order of magnitude superior to the traditional finite element method.

Keywords: finite element method, semi-analytical finite element method, block iteration method, linear and nonlinear equations, elastic and elastic-plastic deformation, Michlin polynomials, curvilinear prismatic bodies.

Баженов В.А., Шкрыль А.А., Максимюк Ю.В.,Мартинюк И.Ю., Максимюк О.В.

ПОЛУАНАЛИТИЧЕСКИЙ МЕТОД КОНЕЧНЫХ ЭЛЕМЕНТОВ В УПРУГОЙ И УПРУГОПЛАСТИЧЕСКОЙ ПОСТАНОВКЕ ДЛЯ КРИВОЛИНЕЙНЫХ ПРИЗМАТИЧЕСКИХ ОБЪЕКТОВ

В данной работе приведены результаты эффективности применения полуаналитического метода конечных элементов к рассмотрению криволинейных призматических объектов в упругой и упруго-пластической постановке по сравнению с классическим методом конечных элементов.

Ключевые слова: метод конечных элементов (МКЭ), полуаналитического метод конечных элементов (ПМКЭ), метод блочных итераций (МБИ), линейные и нелинейные уравнения, упругое и упруго-пластическое деформирование, полиномы Михлина, криволинейные призматические тела.

\section{УДК 539.375}

Баженов В.А., Шкриль О.О., Максим'юк Ю.В., Мартинюк І.Ю., Максим'юк О.В. Напіваналітичний метод скінчених елементів у пружній та пружно-пластичній постановці для криволінійних призматичних об'єктів // Опір матеріалів і теорія споруд: наук.-тех. збірн. - Київ: КНУБА, 2020. - Вип. 105. - С. 24-32.

В статті наведені результати ефективності застосування напіваналітичного методу скінчених елементів до розгляду криволінійних призматичних об'єктів у пружній та пружно-пластичній постановиі в порівнянні з класичним методом скінчених елементів. Табл. 0. Іл. 4. Бібліогр. 6 назв.

UDC 539.375

Bazhenov V.A., Shkril' A.A.,Maksimyuk Yu.V., Martyniuk I.Yu., Maksimyuk O.V. Semi-analytical method of finished elements in elastic and elastic-plastic position for curviline prismatic objects // Strength of Materials and Theory of Structures: Scientific-\&-Technical collected articles - Kyiv: KNUBA, 2020. - Issue 105. - P. 24-32.

This paper presents the results of the effectiveness of the semi-analytical finite element method for the consideration of curvilinear prismatic objects in elastic and elastic-plastic formulation in comparison with the classical finite element method.

Tabl. 0. Fig. 4. Ref. 6.

\section{УДК 539.375}

Баженов В.А., Шкриль О.О., Максим'юк Ю.В., Мартинюк І.Ю., Максим'юк О.В. Полуаналитический метод конечных элементов в упругой и упругопластической постановке для криволинейных призматических объектов // Сопротивление материалов и теория сооружений: науч.-тех. сборн. - К.: КНУСА, 2020. - Вып. 105. - С. 24-32.

В статье приведены результаты эффективности применения полуаналитического метода конечных элементов к рассмотрению криволинейных призматических объектов в упругой и упруго-пластической постановке по сравнению с классическим методом конечных элементов.

Табл. 0. Ил. 4. Библиогр. 6 назв. 
Автор (вчена ступень, вчене звання, посада): доктор технічних наук, професор, академік Національної академії педагогічних наук України, завідувач кафедри будівельної механіки Київького національного університету будівництва $i$ архітектури, директор НДI будівельної механіки БАЖЕНОВ Віктор Андрійович

Адреса робоча: 03037 Украӥна, м. Київ, Повітрофлотський проспект 31, Київський національний університет будівництва і архітектури.

Робочий тел.: +38(044) 245-48-29.

мобільний тел.: +38(067)111-22-33

E-mail: bazhenov.va@knuba.edu.ua

ORCID ID: https://orcid/org/0000-0002-5802-9848

Author (degree, academic rank, position): doctor of technical sciences, professor, academician Of the National Academy of Pedagogical Sciences of Ukraine, Director of the Research Institute of Structural Mechanics Bazhenov Viktor Andriyovych.

Автор (вчена ступень, вчене звання, посада): професор, доктор технічних наук, професор кафедри будівельної механіки КНУБА Шкриль Олексій Олександрович.

Author (degree, academic rank, position): Associate Professor, Doctor of Technical Sciences, Professor of the Department of Structural Mechanics of KNUBA Shkryl Oleksii Oleksandrovych.

Адреса:03680 Украӥна, м. Київ, Повітрофлотський проспект 31, Київський національний університет будівництва і архітектури, кафедра будівельної механіки.

Мобільний тел.: +38(050) 307-61-49.

E-mail: alexniism@ukr.net

ORCID ID: http://orcid.org/0000-0003-0851-4754

Автор (вчена ступень, вчене звання, посада): професор, доктор технічних наук, професор кафедри будівельної механіки КНУБА Максим'юк Юрій Всеволодович.

Author (degree, academic rank, position): Associate Professor, Doctor of Science (Engineering), Professor at the KNUCA Department of Structural Mechanics Maksymiuk Yurii Vsevolodovych.

Адреса: 03680 Украӥна, м. Київ, Повітрофлотський проспект 31, Київський національний університет будівництва і архітектури, кафедра будівельної механіки.

Робочий тел.: +38(044) 241-55-38.

Мобільний тел.: +38(067) 230-94-72.

E-mail: maximyuk@ukr.net

ORCID ID: http://orcid.org/0000-0002-5814-6227

Автор (вчена ступень, вчене звання, посада): кандидат технічних наук, докторант кафедри будівельної механіки КНУБА Мартинюк Іван Юрійович.

Author (academic degree, academic rank, position): candidate of technical sciences, doctoral student of the KNUCA department of structural mechanics Martyniuk Ivan Yuriyovych.

Адреса: 03680 Украӥна, м. Київ, Повітрофлотський проспект 31, Київський національний університет будівництва і архітектури, кафедра будівельної механіки.

Мобільний тел.: +38(096) 068-00-29

E-mail: ivan.martinyuk@gmail.com

ORCID ID: http://orcid.org/0000-0001-7957-2068

Автор (вчена ступень, вчене звання, посада): аспірант Київського національного університету будівнищтва і архітектури Максим'юк Олександр Всеволодович.

Author (Academic Degree, Academic Title, Position): Maksymiuk Oleksandr Vsevolodovych, graduate student of Kyiv National University of Construction and Architecture.

Адреса: 03680 Украӥна, м. Київ, Повітрофлотський проспект 31, Київський національний університет будівництва і архітектури, кафедра будівельної механіки.

Мобільний тел.: +38(067) 306-17-81.

E-mail: sashamaksymiuk@gmail.com

ORCID ID: https://orcid.org/0000-0002-2367-3086 